\title{
手指動作記述文間の類似性に基づく 手話単語の検索方法
}

\author{
安達久 博
}

手話は聴覚障害者と健聴者との重要なコミュニケーション手段の 1 つであり, 手話を 学習する健聴者の数も年々増加する傾向にある。この様な背景から, 近年, 手話の学 習支援システムや手話通訳システムなどの研究が各所で盛んに行われている. 特に, これらの自然言語処理システムの知識辞書となる手話電子化辞書の構築は重要な課題 であり, 手話側から対応する日本語ラベルを効率良く検索する手段の実現は, 日本語 と手話との対訳辞書の検索機能として, 必要不可欠な要素技術といえる. 従来の検索 方法の多くは, 手話単語の手指動作特徴を検索項目とし, 検索条件を詳細に設定する 必要があった。そのため, 初心者には満足する検索結果を得ることが難しいという問 題点が指摘されている。この主な原因の 1 つは, 検索条件の複雑さや検索項目間の類 似性から選択ミスが生じやすく, 結果として, 利用者の要求に適合する検索結果が出 力されないという問題点にある．本論文では，市販の手話辞典に記載されている手指 動作記述文に着目した検索方法を提案する。本手法の特徴は, 検索キーとして入力さ れた手指動作記述文と類似の手指動作記述文を検索辞書から検索し, 対応する手話単 語の日本語ラベルを利用者に提示する点にある。すなわち, 手話単語の検索問題を文 献検索問題と捉えたアプローチといえる．実験の結果，本手法の妥当性を示す結果が 得られた。一方，実験により明らかになった問題点の 1 つとして，手指動作記述文で 表現された手指動作の一部に曖昧さがあることが分かった.この問題を含め, 本手法 の問題点と今後の課題について，例を示しながら詳細に議論する.

キーワード: 手話, 情報検索, 類似度, 手指動作記述文, 電子化辞書

\section{A Retrieval Method of Signs Based on Similarity between Manual Motion Descriptions}

\author{
HISAHIRO ADACHI ${ }^{\dagger}$
}

Sign language is an important path for us to communicate with hearing impaired people. Therefore, learners has been increasing in recent years. There are several researches into learning aid systems and electronic dictionaries for sign language. Especially, when users want to look up the Japanese word labels corresponding with manual motion properties, most of previous retrieval methods are necessary to set various and many retrieval conditions in detail. There is a serious problem that it is hard for beginners to look up the most appropriate sign by the setting wrong conditions. To overcome this problem, this paper proposes a method which uses a different approach from the previous methods. The point of the method is based on the similarity between manual motion descriptions(MMDs) appeared in ordinary sign dictionaries. By computing the similarity between an inputted MMD as a query and the MMDs in the database, retrieval results are outputted in similarity order. 
The retrieval results formed by the similarity can be considered as a set of signs that are similar to each other. As an interesting point, a subject of sign retrieval can be considered as the document retrieval. The results of evaluation experiments show the applicability and usability of the proposed method. We also discuss a problem that there are ambiguous MMDs by demonstrating examples.

KeyWords: Sign language, Information retrieval, Similarity, Manual motion description, Electronic dictionary

\section{1 はじめに}

近年，聴覚障害者の重要なコミュニケーション手段の 1 つである手話と，健聴者のコミュニ ケーション手段である日本語とのコミュニケーション・ギャップの解消を目的とする手話通訳シ ステムや手話の学習支援システムなどの研究が各所で盛んに行われている (安達 1992b).

これら手話を対象とした自然言語処理システムを実現するための重要な要素技術の 1 つであ る手話の認識や生成処理技術は, 動画像処理の研究分野であるが, 対象が限定されているため, 動画像構成の単位を明確に規定できる可能性があり, 手話の知的画像通信や手話画像辞書への 特徵素の記述法が提案されている (黒川 1988; 河合, 田村, 岡崎 1996; 佐川, 酒匂, 阿部 1992; 寺 内, 長嶋, 三原, 長嶋, 大和 1992 ; 長嶋, 神田, 寺内 1993 ; 徐, 棚橋, 坂本, 青木 1993 , など).

また，日本語文の手話単語列文への言語変換処理に関する基礎検討としては，(鎌田, 吉田, 渡辺, 薄井 1994b; 安達, 吉澤, 藤田, 松本, 鎌田 1992; 安達 1992a; 鎌田, 松本, 山上 1994a; 寺内 西川 1996, など) が報告されている。さらに，手話表現の認識結果を基に日本語文を生成する 研究としては，(佐川他 1992; 阿部, 酒匂, 佐川 1993, など) がある。なお,これらの処理精度に 影響を与える電子化辞書の構成方法に関しては, (安達, 下山, 播磨, 松浦 1993 ; 長嶋他 1993; 徳 田 奥村 1998 , など) が提案されている.

さて, 2 言語間の対訳電子化辞書システムを構築する場合の重要な要素技術の 1 つとして, 原言語側と目標言語側との双方向から単語を検索できる機能の実現が挙げられる。ここで, 手話 単語を対象とした場合の課題の 1 つは, 視覚言語としての特徵から, 手指動作表現を検索キー とし, 対応する日本語の単語見出し（以後, 本論文では, 日本語ラベルと略記する。）を調べる 手段をどのように実現するかという点である.すなわち, 視覚情報としての手指動作特徴をど のように記号化して，検索要求に反映させ，検索辞書をどのように構成するかという問題とい える.この問題に対する従来のアプローチは, 手の形, 動き, 位置などの手指動作特徵の属性 を詳細な検索項目として用意し，これらの項目間の組合せとして検索条件を設定し，同様に， これらの検索項目を基に手話単語を分類したデータベースを検索辞書としていた (加藤，内藤， 神田 1993; 内藤, 安東, 加藤 1994, など). この検索アプローチは, 手話言語学における手話単 語の表記法（単語の構造記述におけるコード法）に基づいている (神田, 小田, 本名, 加藤 1984; 
神田, 加藤, 本名, 小田 1985).

しかし，これらの表記法と分類観点は，本来，個々の手話単語の表現を厳密に再現（記述） することを目的としているため (Stokoe, Casterline, and Croneberg 1976), 項目数が多く, ま た，項目間の類似性もあり，初心者には難解なコード体系といえる，そのため，このアプローチ による検索システムの問題点が，(内藤 加藤 1996) により指摘されている. それによると，手 の形，動き，位置などの検索条件を指定する場合，

(1) 検索項目間に類似性が高いものがあり，利用者が区別しにくく，

(2) 検索条件や検索項目が多くなると, 利用者は選択操作が煩わしくなり,

結果として選択ミスを生じ，満足のゆく結果が得られないとされる。これは，利用者が認知し た手話表現の手指動作特徴を再生し, 検索条件に設定する場合に, 不必要な検索条件までも指 定してしまう点に原因があるといえる.

一方, 認知された外界の情報を, ある表現形式（表象）から別の表現形式に変換すること を，一般に，コーディング（符号化）と呼ぶ.また，視覚的な特性を持つ「視覚的コード」と 言語的な特性を持つ「言語的コード」を重要視する「二重コード説」によると，写真などの視 覚情報を記憶する場合に, 視覚的コーディングに加え,「赤い色をした車」のように言語的コー ディングも同時に行われているとされる(大島 1986)，さらに，単語は文字（あるいは音素）の 組み合わせで構成されるが，例えば，(1)「キ」を提示した後で，それは「キ」あるいは「シ」 だったのかを質問した場合と，(2)「テンキ」を提示した後で，それは「テンキ（天気）」あるい は「テンシ（天使）」だったのかを質問した場合とでは，(2)の方が成績が良いとされ，文字の 弁別が単語という文脈内で規定された方がより正確に記憶するとされる「単語（文脈）優位性 効果 (Reicher 1969)」が知られている。これら認知科学の成果を手話単語の検索問題に当ては めて考えてみると，人間が手指動作表現を認知する場合，「両手を左右に動かす」というように， 言語文として言語的コーディングを行い記憶しているとすれば，記憶された言語的コード，す なわち，手指動作特徴を記憶した際の文脈環境を保持する言語文そのものを検索キーとするア プローチが考えられる.

本論文では, 検索条件を細かく指定する従来の方法とは異なり, 手話単語の手指動作特徴を 日本語文で記述した手指動作記述文を検索条件とみなし, 辞書にある類似の手指動作記述文を 類似検索し，検索結果に対応付けられている日本語ラベルを提示する方法を提案する．本手法 の特徵は, 手話単語の手指動作特徵間の類似性を手指動作記述文間の類似性と捉え，入力され た手指動作記述文と辞書に格納された手指動作記述文との類似度を計算する点にある.すなわ ち,「手話単語の検索問題を文献検索問題と捉えたアプローチ」といえる．また，この手指動作 記述文は，一般に，市販の手話辞典に記載されており，手話の学習者の多くが，慣れ親しんで いる文形式と捉えることができる.

なお，本提案手法に関連する研究として，翻訳支援を目的とした対訳用例の類似検索に関 
する研究が幾つか報告されている (中村 1989; 隅田 堤 1991; 佐藤 1993; 田中, 熊野, 浦谷, 江原 1999,など). これらにおいては, 文間の類似度の計算に用いる照合要素として, 文字を対象と する方式と単語を対象とする方式に大別することができる．また，これらの要素間の照合戦略 としては, 出現順序を考慮しながら共有要素を計算する方式 (以後, 順序保存と略記する.) と, 出現順序を考慮しない計算方式 (以後, 順序無視と略記する.) に大別することができる.ここ では，照合要素が文字列と単語列という違いはあるが，順序無視と順序保存の照合戦略を用い た代表的な 2 つの手法について概説する.

(佐藤 1993) は文字の連続性に着目した文間の類似性を基準に,「最適照合検索」として, 順 序保存を採用した検索システム（CTM1）(Sato 1992）と順序無視を採用した（CTM2）の検索 効率を比較し，ほぼ同等であるが順序無視の方が若干優位としている。一方，(田中他 1999) は, 放送ニュース文の単語列を対象に, AND 検索に順序保存の制約条件を加え, 長文に対する効果 的な用例検索法を提案し, 順序保存の方が優位としている. なお, 両者とも類似性を計る指標 として, 語順（あるいは文字の出現順序）を考慮するアプローチの重要性を指摘している。こ のことは, 文構造の類似性を表層情報として得られる文形式 (単語の配列順序) の類似性を文 間の類似度に加味することの意義を示唆している.

以下, 2 章で, 手指動作記述文の特徵について述べ, 3 章では, 手指動作記述文間の類似度 と手話単語の検索方法について述べ, 4 章で, 提案手法の妥当性を検証するために行った実験 結果を示す. 5 章では, 実験により明らかとなった問題点について議論し, 今後の課題について 述べる. 最後に, 6 章で，まとめを行う.

\section{2 手指動作記述文の特徵}

一般に, 市販されている手話辞典の多くは, 手話単語の日本語ラベルに対して, その手指動 作表現の手続きをイラスト以外に，日本語文で表現した手指動作記述文を記述している(丸山 1984; 手話研究委員会編 1986, など). そこで, 以下に示す手話単語対の「午前」と「午後」を 例に考えてみると, この単語対は, 手指動作特徵の中で「手の動き（右に倒すのか左に倒すの か)」に関する手指動作特徵だけが異なる手話単語の最小対を構成している. 明らかに，与えら れた手指動作記述文間の比較からも，この関係を導出することができる.

(1) 午前 右手の人差指と中指を立て額の中央に当て右に倒す

(2) 午後右手の人差指と中指を立て額の中央に当て左に倒す

このように, 手指動作記述文は, 手話単語の手指動作表現の特徵構造を, 構造を持つ 1 次元 の記号系列（言語文）に写像した特徽系列と捉えることができる.この特徵系列は, 日本語文 であり，文法構造を内在しており，手話単語の手指動作表現を生成するための手続きを記述し たプログラム（手続き文）と捉えることもできる. 
また，手指動作記述文は一般の自然言語文に比べ，文中で用いられる語彙には，ある種の制 約があると捉えることができる，例えば, 名詞は手指動作表現を特徴付ける手や顔, 胸などの 身体の上半身の部位を表すものに限定されている．また，動詞は手指の形や動きを表現するも のに限定されている，さらに，副詞は手指動作の強弱や反復などの程度を表すものに限定され ている.

同様に, 動作表現を生成する手続き文としての特徴から，文中での単語の配列（文形式）に， ある種の構文パターンがあると考えられる. 例えば,「午前, 午後」の例が示すように,「手の形, 手の位置, 手の動き」の順に手指動作特徴を表す単語列が配列されている.

これらの特徵から, 手指動作記述文は言語の使用環境が, 一般の自然言語文に比べて, 語彙 的にも構文的にも強い制約を受けた有限の文集合と捉えることができる.

\section{3 手指動作記述文を用いた手話単語の類似検索}

(安達 2000) は，与えられた単語集合から類似の手指動作特徵を含む手話単語対を抽出する方 法として, 手話単語間の手指動作特徵の類似性を手指動作記述文間の類似性と捉えたアプロー チによる方法を報告している。そこでは, 手指動作記述文を, 文を構成する文字配列を特徵観 点とする $n$ 次元の特徴ビットベクトルで表現し, 以下に示す文間の類似度の計算式 (1) を導出 している.

$$
S(A, B)=\frac{L C S(A, B)^{2}}{M \cdot N}
$$

ここで, $M, N$ はそれぞれ, 手指動作記述文 $A, B$ の長さ（文字数）を表し, $L C S(A, B)$ は最長 共有部分列の長さ (Thomas, Charles, and Ronald 1990) を表している.

\section{1 手話単語の類似検索への適用}

(安達 2000) では，ある 1 つの辞書に記載の手指動作記述文の文集合をその処理対象として いる。一方, 本論文で対象とする手指動作記述文の文集合は, 検索データベース, すなわち, 検 索辞書としての手指動作記述文 (以後, 辞書記述文と略記する。) と, 検索要求としての手指動 作記述文 (以後, 検索記述文と略記する.) というように, 異なる 2 つの文集合を対象とする必 要がある.すなわち，一般の情報検索システムで問題となる利用者の質問と辞書との表現上の 差 (長尾 1983) の問題と同様に, 検索記述文と辞書記述文とのギャップについて考慮する必要が ある。

例えば, 辞書記述文は手話表現を生成する手続き文（プログラム文）としての特徵から, 手 の形, 手の位置, 手の動きなどの手指動作特徴を詳細に記述していると捉えることができる ${ }^{1}$. 1 必ずしも, 全ての手指動作特徴を洩れなく記述している訳ではなく, イラストの情報との相補関係にあり, 省略されて いる特徴素もある 
一方，検索記述文は手話の学習者の入力を想定しており，辞書記述文に比べ特徵素の省略など により，より簡潔な文となる可能性が高い。しかし，手話の学習者が日常，手話単語を学習す る際に参考としている手話辞典等で，慣れ親しんでいる辞書記述文と類似の文形式で入力する であろうと考えることができる.

そこで, 本研究では，このようなギャップがある手指動作記述文間の類似性の計算に適応さ せるため, 検索記述文と辞書記述文の両者を疑似文節列に分割し, 各疑似文節から平仮名以外の 文字列のみを抽出した非平仮名キーワード列を特徴観点とした類似度の計算を行うこととする.

\section{2 疑似文節列と検索キーワード列の抽出}

漢字かな混じりの日本語文を形態素解析処理を用いないで, 文節列に区切るヒューリステイッ ク・ルール（経験則）として，以下に示す字種の違いに着目したものが考えられる.

\section{文節区切りの経験則}

平仮名文字が非平仮名文字へ字種が変位する境界部分を文節の区切りとする

例えば,「両手を交互に上下させながら左右に引き離す」をこの経験則で分割すると、『両手 を/交互に/上下させながら/左右に/引き/離す』となる。この分割結果を本論文では，疑似文節 列と呼ぶ。ここで,「疑似」という用語を冠した理由は，以下に述べるように，一般に，文節と は認定できない分割結果を含む場合があるためである。

\section{経験則の問題点と利点}

先に示した経験則による文節分割の問題点は，上記の例文にある複合動詞「引き離す」の ような混ぜ書きで表現される文要素を分割してしまう点と,「上下させながら」のように平仮名 で表記される文要素は分割できない点である。しかし，上記の例文を辞書記述文とし、検索記 述文に同じ意味を表す別の表現として「〜を左右に引く」や「〜を左右に離す」があった場合， 混ぜ書きされた文要素を分割してしまう経験則の不具合は，逆に，このような同義関係にある 文要素同士を類似度に反映できる利点があると考える。一方，この文字列の照合処理において， 完全一致では動詞の活用部分の差や用いられる助詞の差（例えば,「左右に」と「左右へ」の関 係）など，自然言語表現の持つ「語形の多椂性」により同一視が難しいのは明らかである.

\section{疑似文節列から非平仮名キーワード列へ}

そこで，疑似文節列から語幹に相当する非平仮名列のみを抽出し，照合処理の対象キーワー ドとし，語形の多様性を吸収することとする，これにより，与えられた手指動作記述文からの 


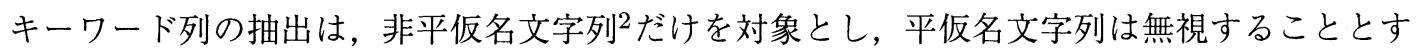
る.このため, 漢字やカタカナで表記されていない文要素は類似度の計算では考慮されず, 仮 に，その文要素がその手話表現を特徵付ける場合であっても，類似度には反映されないという 問題は残るが，本論文では，他の文要素間の類似性により文間の類似性を近似することとし， この問題は今後の課題とする.

以上の議論から, 検索記述文と辞書記述文との類似性を近似する類似度は，与えられた手指 動作記述文から非平仮名の連続文字列を照合要素とし, 以下に示す式 (2) を用いて計算する.こ こで，式 (1) と区別するため， $M_{k}, N_{k}$ はそれぞれ，手指動作記述文 $A, B$ の非平仮名キーワー ド列の総数であり, $\operatorname{LCS}_{k}(A, B)$ は両者の最長共有キーワード部分列の長さを表す。なお, 照合 の際に次節で述べる「語選択の多様性」に対処する処理を適用する。

$$
S(A, B)=\frac{L C S_{k}(A, B)^{2}}{M_{k} \cdot N_{k}}
$$

\section{3 キーワード照合における不要語と同義語の扱い}

一般に, 文献検索システムでは, 出現頻度が高く文献の特徵付けに寄与しないキーワードを 不要語 (stop word) として, 検索対象キーワードから除外する方法が採られる. 手話単語は, 一般に, 両手の形が同一である「両手同形」, 形が異なる「両手異形」と片手で表現する「片 手」の 3 種類に大別される.ここで, 両手同形の手話単語を例に考えると, 市販の手話辞典に 記載の手指動作記述文には，以下に示す例文 (1) と (2) のように,「手の形」を規定する部分が 「両手」に対して, 前置される場合と後置される場合が混在している。

（1）五指を折り曲げた両手を交互に上下する

(2)両手の五指を折り曲げて交互に上下する

キーワードの出現順序を考慮する照合戦略では, 利用者の検索要求を表す検索記述文が例文 (2) と同一であった場合, 例文 (1) の共通キーワード数は例文 (2) より少なくなる.この照合洩 れを抑止するために,「両手」を不要語として, 検索記述文と辞書記述文の両方から除外すれば, 例文 (1) と (2) の共通キーワードの数は同一となる. 同様に, 片手手話に分類される単語は, 手 話単語の基本形であり，一般に,「右手」を用いて表現する。 そのため, 利用者の検索記述文中 で省略される可能性がある。このように, 検索システム全体の構成として, 最初に, 両手同形 なのか片手の手話なのかを利用者に指定させることで，片手手話の検索の際には「右手」を， 両手同形手話の場合には「両手」をその照合対象から除外する戦略は, 類似検索の照合処理に 有効に機能すると考える.

2 漢字に限定しないのは, 指文字等は一般にカタカナで表記される傾向がある点と, 平仮名書きの文要素を, カ夕カナで 表記あるいは置換できれば, 比較的容易に類似度に反映させることが可能と考えたためである.なお, カ夕カナへの置 換は今後の課題とする. 
次に，検索記述文と辞書記述文のキーワードの一致を前提に照合を行なう本手法では，本来， 同一であるべき照合要素が言語の多様性により別の表現となり，一致しない場合がある．例え ば,「前方に出す」と「前に出す」の関係における「前方」と「前」との不一致である．また，手 の動作位置などに関して，利用者の認識と辞書側の記述表現の差，すなわち，全体/部分の関係 の捉え方の違いに起因する不一致が考えられる。例えば，辞書記述文では「胸の前」と記述され ている部分に対して，利用者の検索記述文では「体の前」と記述する場合である，同様に,「口 の前」と「顔の前」などが対応する，そこで，本手法では表 1 に示すように，キーワード間の照 合で同一視する同義置換表を用意し，これら「語選択の多様性」の一部を吸収することにする。

このように，前節で述べた平仮名文字列を照合要素から除外する戦略が，語形に関する多様 性に対処する枠組であり，本節で述べた処理は語選択の多様性に対する枠組と捉えることがで きる。

表 1 照合時に同一視するキーワード間の同義置換表の一部

\begin{tabular}{l|l}
\hline 同一視するキーワード群 & 文中で用いられる例 \\
\hline \hline 前, 前方 & (前, 前方)に出す \\
\hline 伸, 立 & 親指を(伸ばす, 立てる) \\
\hline 開, 離, 広 & 左右に (開く, 離す, 広げる) \\
\hline 体, 胸, 腹 & 而手を(体, 胸, 腹) の前に \\
\hline
\end{tabular}

\section{4 実験と評価}

本手法の有効性を確認するため, 本論文では, 両手同形の手話単語集合を対象として, 実験 を行う. (内藤・加藤 1996) の調査分析によれば, 両手同形の手話単語は手話単語全体 $(2,524$ 語）の $41.7 \%$ を占め, その中の $90 \%$ は両手の移動を伴う手話単語であり, 移動を伴う手話単語 は手話単語全体の $84 \%$ と報告されている。また，(鎌田, 藤野, 薄井 1991) は, 手指動作特徵の 中で「手の動き」の重み付けは，他の特徵素よりも大きいと指摘している．これは，(内藤・加 藤 1996) の分析でも両手同形の手話単語は他の夕イプの手話単語に比べ,「手の形」が限定され ており，手の動きが単語の弁別特徵素として働く割合が高い手話単語であるとの調査結果と一 致する.

これらの分析から，手話単語の大部分が動きを伴う表現であり，特に，両手同形の手話単語 では，その割合が高く，本論文で提案する手法の妥当性を検証するのに適していると考える.

\section{1 実験データとその特徵}

実験データは以下の手順で準備したものを用いた。まず，検索記述文として「わたしたちの 手話 (1)」(手話研究委員会編 1986) に記載の手指動作記述文を, 辞書記述文として「イラスト 
手話辞典」(丸山 1984)に記載の手指動作記述文を用い, 文字列「両手」を含む両手同形の手話 単語を抽出した。なお, 複合手話表現と明示されている手話単語は, 実験対象から除外した.

次に, 実験結果の分析・評価を明確にするため, 抽出された検索記述文の日本語ラベルが, 辞書記述文の文集合（613 文）の日本語ラベルと対応関係にある検索記述文を選択し，最終的 な検索記述文の文集合（87 文）とした。ここで，両者の原辞書間で日本語ラベルが一致しない ものがあるため ${ }^{3}$, 原辞書の索引等を比較し，検索記述文の手話単語が辞書記述文に確実に含ま れる検索記述文を選定し，人出により計算機に入力したものを実験データとして準備した.

なお，表 2 には，検索記述文と辞書記述文の文字数の分布状況を示す．ここで, 辞書記述文 より検索記述文の方が短い文で構成されていることから，大まかな動作特徵を検索キーとする 傾向にある利用者側の要求を反映した実験データと捉えることができる.

表 2 実験に用いた手指動作記述文の文字数による比較

\begin{tabular}{r|r|r|r|r|r|r}
\hline & 総文数 & 平均字数 & 最大字数 & 最小字数 & 20 字未満 & 20 字以上 \\
\hline \hline 検索記述文 & 87 文 & 18.85 & 32 & 7 & 48 文 & 39 文 \\
\hline 辞書記述文 & 613 文 & 31.71 & 78 & 10 & 48 文 & 565 文 \\
\hline
\end{tabular}

\section{2 実験方法}

実験は，まず，1 次情報である検索記述文から非平仮名文字のみを検索キーワード列として 抽出した 2 次情報を作成する. 同様に, 辞書記述文から抽出した非平仮名キーワード列の 2 次 情報を作成する。そして, 2 次情報同士の文字列照合により類似度を求め, 類似度の值が高いも のほど上位に位置するように整列したものを検索結果とする. なお, 共通キーワード数の計算 には, 順序保存と順序無視の照合方式をそれぞれ用いた類似度を計算し, 検索結果を比較する. ここで, 順序保存の類似度は式 (2) で計算し, 順序無視の場合には, 式 $(2)$ の $\operatorname{LS}_{k}(A, B) を$, 重複を許す形で照合を行なった共通キーワード数 $C_{k}(A, B)$ として類似度を計算する. また, 2 次情報との比較のため, 与えられた 1 次情報の文字を照合要素とする類似度を式 (1) を用いて 同様に計算し，検索結果を比較する。

\section{3 評価方法}

一般に, 情報検索システムあるいは手法を評価する場合, 利用者側の立場からみた検索効率 を評価する尺度として, 従来, 呼出率と適合率が用いられてきた。ここで, 呼出率とは, 被検 索対象である文書集合の中で，検索要求文に適合すると判断できる文書総数と，実際に検索さ れた適合文書数との比で計算される. 一方, 適合率は検索された文書総数と, その中の適合文

3 例えば, (離れる, 別れる), (月日, いつ), (つまり，まとめる)，(失う，なくす) などの対応関係を同定した. 
書数との比で計算される。なお, 最近では, これらの指標が利用者の多様な検索要求に対して, 必ずしも適切な評価尺度とはならないとの問題点が指摘されている (徳永 1999). 本論文で対象 とする手話単語を検索する場合, 検索要求に適合する辞書の手指動作記述文は原則として $1 つ$ である。すなわち，複数の適合手指動作記述文（に対する手話単語）を前提としていないため, 適合率と呼出率による検索効率の評価は適していないと考え ${ }^{4}$, 以下で述べる評価尺度を用いる ことにする.

\section{平均検索成功率}

手話単語の検索の場合，一般的に，利用者の第一義的な検索要求は,「当該手話表現の日本語 ラベルは何かを知りたい」であり，順序付けられた検索結果の上位に，対応する日本語ラベル が位置することが検索システムには求められる。

さらに，現実的には，利用者は当該手話表現に適合する検索結果を上位から逐次調べる必要 があるため，その手間数が少ない方が良い，すなわち，利用者の立場から見ると，その当該手 話単語が見つかれば要求は満たされ，原則，それ以上は調べる必要性はない。

しかし，手話単語を学習（手話表現を習得し理解を確実に）するためには，類似の動作特徴 を持つ他の手話単語との関係を同時に学習することは重要である.一般に, 音声言語の単語習 得においても，他の単語との関係から当該単語の特徵や役割について理解することは，学習効 果を高めるといわれている。この類似の動作特徵を持つ手話単語も同時に検索することが，本 論文で提案する検索方法の重要な目的の一つである.

そこで, 本論文では, 適合性の評価尺度として, 検索結果の上位に位置するある規定範囲内 で検索されたか否かの二值的な判断により，質問集合全体の総数と各質問に対する検索数の比 で求まる「平均検索成功率」を評価指標とする。

\section{平均到達度数}

一方, 検索結果の順序付けは類似度に応じて整列されるが，類似度の值が同じため同順位と なる場合があり，適合部分集合の要素は複数となる。そのため，1位で検索された場合でも，同 順位のものが 10 個あると, 正解とみなされる手話単語に到達するまで, 利用者は最悪で 10 回 の手間を必要とする。この利用者が適合する結果に到達するまでの手間を評価尺度とする方法 として，(Cooper 1968)の平均探索長 (expected search length) がある.

そこで，本論文では，評価尺度として，平均探索長の考えに基づく,「平均到達度数」を定義 し, 評価指標として用いることにする. 平均到達度数は, 平均探索長が同順位以外も含め, 複 数の適合文書の検索を想定して計算する必要があるが，本実験では，適合文書に対応する辞書

4 現実には, 予め, 同一の手話表現に対する手指動作記述文を 1 つにマージしてない場合, 複数の適合文が存在すること になるが，すべての検索要求に対して，複数の適合文がある訳ではなく，その数は限られている. 
記述文は，検索記述文の手話単語に対応する唯一の手指動作記述文を対象として評価したいた め，適合辞書記述文を含む同順位の組み合わせだけを考慮すれば良いため，以下のように計算 は比較的簡単化される.

任意の検索要求に対して，同順位 $i$ 番目で検索される部分集合の要素数を $P(i)$ とする．ま た, 当該手話単語が含まれる順位を $n$ とすると, 期待值としての平均到達度数 $E L$ は次式で求 められる.

$$
E L=\sum_{i=1}^{n-1} P(i)+\sum_{i=1}^{P(n)} \frac{i}{P(n)}
$$

ここで, すべての検索要求に対して, 必ず $m$ 個の検索結果を出力するものとすると, 到達 度数の最小值は 1 であり, 第一番目に当該手話単語が検索され, かつ, 同順位のものがない場 合となる．また，最大值は出力された $m$ 個をすべて調べる場合で $m$ となる ${ }^{5}$.

\section{有用性の評価}

有用性の観点からの評価と適合性の観点からの評価とは, 一般に, 直交する概念と捉えられ る.すなわち, 適合する文書ではなくても, その文書が, 利用者にとって有用な情報を含んで いる場合があり，その観点で有用性が評価される，最近では，二值的な判断でなく多值的な判 断を採り入れ，より詳細に適合性や有用性を評価している (佐藤 1993; 田中他 1999).

本論文では, 検索結果を有用性の観点から評価するため, 各検索記述文に対する上位 10 位 までの検索結果の手話単語を求め, 得られた手話単語に対して, 以下に示す評価値をつける.
A 検索記述文の手話単語と一致する.
B 検索記述文の手話単語と手の形, 位置, 動きの中で 1 つだけ異なる最小対である.
C 検索記述文の手話単語と類似の動作特徴を含む.
$\mathrm{F}$ 類似の動作特徵を何も含まない.

また，各検索記述文に対する検索結果全体の評価は，上記の評価值の組み合わせとして，以 下に示す総合評価値を与える，すなわち，A を含むか否か（適合性）も加味された評価となる.
AB A と B を含む
AC A と C を含む

A A を含む

BC B と C を含む

B B を含む

C C を含む

F A,B,Cいずれも含まない.

5 検索に失敗した場合も, すべての出力結果を調べるため手間数は同等になる. また, 同順位の要素数を含め $m$ 個を超 えた場合，超えた分は検索されなかったものとみなす。 


\section{4 結果と評価}

\section{平均検索成功率による評価}

表 4.4は, 同順位で 10 位（上位から 10 番目）までの検索結果に対する平均検索成功率を示 す。ここで, 順序保存と順序無視による照合について, 文字を照合要素とした場合, 非平仮名 キーワード列を照合要素とした場合との組み合わせによる検索結果を示している．欄中の最初 の数值が検索要求総数 (87 件) の中で 10 位以内で検索に成功した数を示し, 括弧の中は平均 検索成功率を示している.

表 3 上位から 10 番目までの平均検索成功率

\begin{tabular}{l|l|l}
\hline 照合方式 & 文字 & キーワード \\
\hline \hline 順序保存 & $52(59.8 \%)$ & $61(70.1 \%)$ \\
\hline 順序無視 & $44(50.6 \%)$ & $55(63.2 \%)$ \\
\hline
\end{tabular}

明らかに，順序保存による照合が，順序無視に比べて平均検索成功率で優位にあることが分 かる，同様に，照合要素をキーワードとした照合が，文字に比べて優位にあることが分かる． 以上の結果から，本提案方式の順序保存・キーワード照合の組み合わせが優位にあり，上位 10 位以内で $70.1 \%$ の平均検索成功率を示している.

\section{平均到達度数による評価}

次に，平均到達度数をキーワード列を用いた順序保存による照合と順序無視による照合との 計算結果を表 4 に示す. その結果, 順序保存による照合方式の平均到達度数は 5.01 となり, 順序 無視による照合に比べて 0.24 優位にあることが分かる，一方，検索に成功した場合の平均到達 度数では, 逆に 0.24 の差がある。このように, 上位 10 位以内に適合手話単語が含まれる場合, 両者とも平均すると検索結果の上位 3 位以内に適合手話単語が位置していることを示している.

表 4 非平仮名キーワード列による検索結果

\begin{tabular}{c|c|c}
\hline 照合方式 & 成功時の平均到達度数 & 全検索要求に対する平均到達度数 \\
\hline \hline 順序保存 & 2.99 & 5.01 \\
\hline 順序無視 & 2.75 & 5.25 \\
\hline
\end{tabular}

\section{有用性の観点からの評価}

図 1に評価結果の例を示す。この例の場合，入力された検索記述文の手話単語は【競技】で あり，第 1 位で検索されたものが対応し，評価 $\mathrm{A}$ が与えられる。また，【競う】，【試験】は「手 
【競技（137)】＝(競技)：親指を立てた両手を交互に前後させる

key $\operatorname{token}(4)=$ 親指 立 交互 前後

A $10.800 \operatorname{lcs}(4) \mathrm{m}(5)$ 【競技】親指 立 交互 二度 前後

B $20.450 \operatorname{lcs}(3) \mathrm{m}(5)$ 【競う】 親指 立 交互 二三度 上下

B $30.375 \operatorname{lcs}(3) \mathrm{m}(6)$ 【試験】親指 左右 立二度 交互上下

C $40.321 \operatorname{lcs}(3) \mathrm{m}(7)$ 【話】人差指 立口前 二度 交互 前後

B $50.281 \operatorname{lcs}(3) \mathrm{m}(8)$ 【売買】

親指 人差指 輪 作 左右 交互 前後 動

図 1 検索結果の有用性の評価例

の動き」が異なる最小対であり ${ }^{6}$ 【【売買】は「手の形」が異なる最小対であり，いずれも評価 $\mathrm{B}$ となる。一方，【話】は「手の形」と「手の位置」が異なるため, 最小対とは認められず, 評価 $\mathrm{C}$ となる。その結果, 検索結果全体の総合評価值は, $\mathrm{A}$ と B を含むため, 最良值として, $\mathrm{AB}$ のグレードが与えられる。

評価結果を表 5 に示す。総合評価が $\mathbf{B}$ 以上は 71 個で, 全体の $81.6 \%$ ある。 また, 総合評 価が $\mathbf{C}$ 以上は 78 個で, 全体の $89.7 \%$ を示している。このことから, 検索に成功した場合には, 類似の動作特徵を含む他の手話単語との比較が可能であり, 適合手話表現と類似手話表現との 弁別特徵の差や, 意味の類似性や相違性を確認できるなど, 手話単語の学習効果に貢献する有 用な情報が検索できたといえる。

表 5 検索結果の有用性の評価

\begin{tabular}{|c|c|c|c|c|c|c|c|c|}
\hline 評価值 & AB & $\mathbf{A C}$ & $\mathbf{A}$ & $\mathbf{B C}$ & $\mathbf{B}$ & $\mathbf{C}$ & $\mathbf{F}$ & 合計 \\
\hline 計 & 52 & 9 & 0 & 8 & 2 & 7 & 9 & 87 \\
\hline A 区分総計 & \multicolumn{3}{|c|}{$61(71.1 \%)$} & \multicolumn{4}{|c|}{$26(29.9 \%)$} & 87 \\
\hline B 区分総計 & \multicolumn{5}{|c|}{$71(81.6 \%)$} & \multirow{2}{*}{\multicolumn{2}{|c|}{16}} & 87 \\
\hline C区分総計 & \multicolumn{5}{|c|}{$78(89.7 \%)$} & & & 87 \\
\hline
\end{tabular}

一方，該当手話単語の検索に失敗した場合には，その中の $38.5 \%$ は適合手話単語の最小対を, また， $65.4 \%$ は類似の動作特徴を含む手話単語の検索に成功していることから, 利用者が「この 表現は, ちょっと違うんだけど, よく似てる」と判断した場合, その辞書記述文を新たな検索記 述文として再利用できる可能性がある。すなわち, 検索のリカバリー処理を同じ枠組で実現で きる.この場合, 次章で議論するように, 辞書側の手指動作記述文の正規化がリカバリー処理 による検索成功率を向上させるための課題である.

これらの評価結果から, 検索結果の上位 10 位以内に, 検索要求に適合する手話単語を含む 割合は約 $70 \%$ でり，平均すると上位から 5 個程度までを調べれば，当該手話単語を見つけら れる. また, 最小対などの類似の動作特徵を含む手話単語を検索結果に含んでおり, 手話単語 の学習効果の向上に貢献し, 上位での検索に失敗した場合のリカバリー処理にも利用できる有 6 明らかに, 図1に示した「競う」と「試験」は同一の手話表現である. 


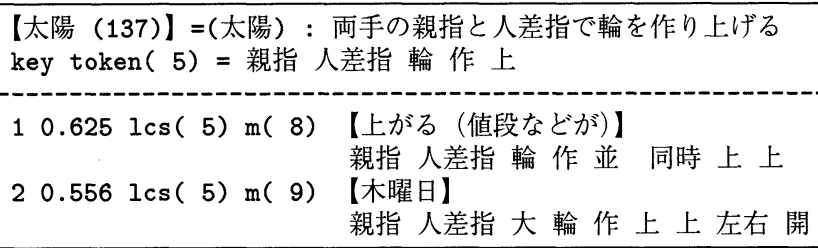

図 2 手指動作記述文の解釈に曖昧さがある例

用な情報を含む手話単語（辞書記述文）を検索しているなど，本論文で提案した手話単語の検 索方法の妥当性を示す結果が得られたと考える.

\section{5 検討}

本章では, 実験により明らかになった問題点と今後の課題について議論する，特に，上位で の検索に失敗した検索結果を分析し，検索例を示しながら議論を行う。ここで取り上げる問題 の幾つかは，本論文で提案した手法に限らず，他のアプローチによる手話単語の検索方法にも 共通の課題を含んでいると考える.

\section{1 手指動作記述文の解釈における曖昧さ}

実験により明らかになった問題点の 1 つは，同一の手指動作記述文の表す手指動作表現の解 釈に，曖昧さがある点である，すなわち，文が複数の解釈を持つ場合があるという自然言語表 現に特有の多義性の問題と捉えることができる7 ${ }^{7}$.その結果, 検索記述文に非常に類似した辞書 記述文が検索された場合でも，利用者の意図した検索要求の手話表現とは，まったく異なる手 話表現が上位で検索されてしまう問題である.

例えば，手話単語の日本語ラベル【太陽】の検索記述文に対する検索結果の例を図 2 に示す. なお，図中の点線の下部は検索結果を示し，1 番目の数字は順位を示し，2 番目の数値は類似度 を示す．また，“lcs”の括弧付きの数字は順序保存による共通キーワード数，“m”の括弧付きの 数字は辞書記述文のキーワード数をそれぞれ示している.

ここで，検索記述文「両手の親指と人差指で輪を作り上げる」が意図する手話表現は,『両手 を使って太陽を模倣した大きな輪を 1 つだけ作り，それを上にあげる』という手指動作を意味 している。一方，第 1 位で検索された手話単語の日本語ラベル【上がる（值段などが）】の手話 表現は,『右手と左手のそれぞれで親指と人差指を使って小さな輪を作り ${ }^{8}$, その 2 つの輪を並べ て同時に上に上げる』手指動作を意味している.

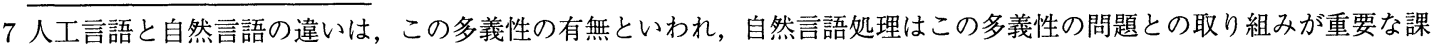
題といえる.

8 「お金」の意味として, しばしば用いられる手話表現の 1 つである. 


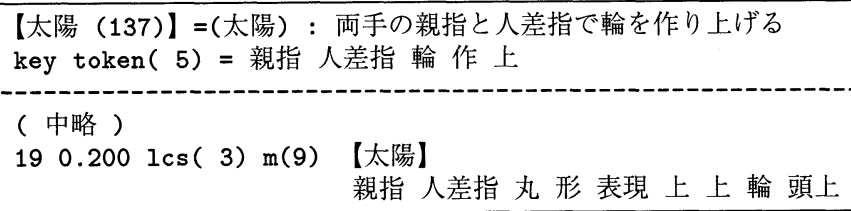

図 3 辞書記述文と検索記述文の違い

このように，両手を用いた表現に対して，検索側と辞書側の記述文の解釈に差が生じる場合 がある。しかし，類似の文構造を持つ「両手の親指と人差指を立て（伸ばし）て〜」などでは， 手話表現に上記のような 2 つ解釈は生じない. また，同様な多義性を持つものとして,「親指 と人差指（の指先）を付け合わせる」の例を考えてみる．片手でこの表現を自然に行うと，い わゆる「小さな輪」になるであろう。一方．両手で表現する場合には，大きな輪以外に四角や 三角も表現できる可能性がある，そのため，可能な解釈を絞り込む情報が付加された,「両手の 親指と人差指（の指先）を付け合わせて輪を作り〜」のような，圥長な表現とも取れる手指動 作記述文が，実験で用いた辞書記述文に存在する。

さらに，第 2 位で検索された【木曜日】の例では,「輪」に関する解釈はほぼ一致している が、【陽】の輪は，動作主である人間の身体に対して平行な位置関係であるのに対し，【木曜日】 のそれは, 垂直な位置関係で表現する違いがある。この位置関係の差に関する情報は, 検索側 と辞書側の記述文には陽に表現されていない. 実験に用いた手指動作記述文は, 市販の手話辞 典に記載のものであり，イラストとの併用を前提として記述されているため，イラストで理解 できる情報の一部が手指動作記述文から省略されている場合がある。

\section{2 語彙の多様性}

次に, 構造的な解釈の曖昧さと同様に, 語彙的な表現の差が検索結果に与える影響について 議論する. 図 $3 に$, 辞書側の【太陽】の記述文から抽出されたキーワードを示す。ここで,「輪」 が「丸」,「作 (る)」が「表現」というように，使われている表現が異なるため，文字列照合の 不一致が類似度に反映されない問題である. そこで, 表 1 に示したキーワード間の同義置換表 に,この 2 つの同義関係（輪, 丸）と（作, 表現）を追加した結果, 図 4に示すように, 同順位 で第 2 位で検索されることを確認した。このように，今後，キーワード間の同義置換表を整備 することで検索精度を向上できる可能性がある。しかし, 同義置換表による「同一視」は, 安 易な追加・変更が文字列の照合処理に副作用を生じる可能性もあり, 同義置換表の拡充 ·利用 法の検討は今後の課題とする.

\section{3 視点の違いによる記述表現のゆれ}

（1）指先を上に向けて付け合わせた両手を左右に引き離す 


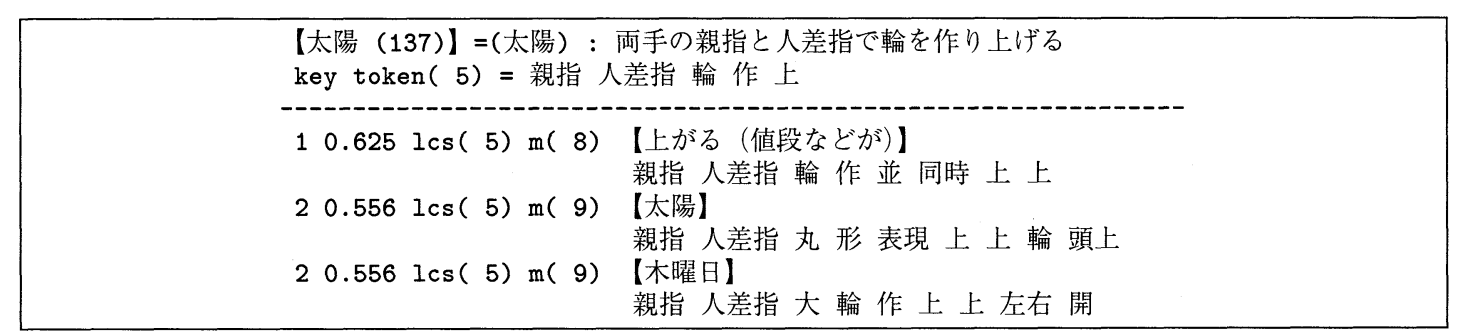

図 4 同義置換表の変更による検索結果の違い

（2）掌を前方に向けて付け合わせた両手を左右に引き離す

上記の (1) と (2) に示した手指動作記述文は, 同一の手話表現を表し, (1) が検索記述文であ り，(2) が辞書記述文の適合文である，結果として，検索結果の上位では (2) は検索されなかっ た，上位で検索されたものは，すべて共通のキーワード列「指先，付，合，左右」をこの配列 順序で照合されたものであった。このキーワード列から類推できるのは,「指先を付け合わせた 手の形」が自然であり，前節で議論した「輪」の表現に相当する。このため,「手の形」が異な る類似の手指動作特徴を含む手話表現（手話単語）は上位で検索されたが，利用者の第一義的 な要求に応える検索結果を上位で提供できないという問題である.

一般に，2つのオブジェクトがある位置関係を持つ場合，その位置関係を文で記述するには 2 つの視点が考えられる。例えば,「Aの左に B がある」と「Bの右に A がある」の関係である. 手話単語の手指動作表現を記述する場合，(1) と (2) で記述される手話表現の手の形は, 基本形 の 1 つであり,「掌の方向」と「指先の方向」は連動して変化する場合が多い. 例えば,「掌を下 に向ける」ことは「指先を前方に向ける」ことになる.

この「視点」すなわち, 手指動作特徴のどこに焦点をおき, 手指動作記述文を記述するかに ついて, 実験に使用した 2 つ手話辞典では, 辞書記述文と検索記述文のいずれでも統一はさ れていない.このように, 手指動作記述文の正規化の問題は, 前節の議論と同様に, 本提案手 法の検索精度を向上させる上で重要な課題の 1 つといえる.

なお，今回の実験では，市販の手話辞典に記載の手指動作記述文を辞書記述文と検索記述文 の双方に用いているため, 顕在化していないが，実際に利用者の検索記述文を入力とする場合 に考慮すべき「視点の問題」として, 左右方向の逆転現象がある.手話辞典の多くは, 手話表現 の動作主体から見た左右方向を記述している. 一方, 利用者は手話表現の動作主体と対面する 形で手話表現を見ているため, 利用者から見た左右の方向を記述してしまう傾向がある. しか し, この利用者が間違った記述をしたか否かの判断は, 検索システム側では対処不能と考える. 


\section{4 動作表現の認識に関する曖昧さ}

手話単語の検索問題では，この語彙に関する問題以上に，利用者側の手話表現の捉え方と辞 書側の手話表現の捉え方が問題となる．前述した事例以外に，(a)「両手を二度ほど下におろす」 表現と (b)「両手を上下に動かす」表現を「同一視」するか否かである．厳密には，(a) はある 始点位置を動作の上限位置と定め, その範囲で下方に二度, 両手を下げることを意味し, (b) は ある始点位置を基準に上方/下方両方の範囲で両手を上げ下げすることを意味すると捉えること ができる．辞書側で (a)を「手を下にだけ動かす」手話単語群に分類し，(b) を「手を上下双方 に動かす」手話単語群に分類していた場合, 利用者が (a)を「上下運動」と捉えたなら，(b)に 分類された手話単語群しか検索されないことになる。このように，この問題は，動作表現を言 葉で表現した手指動作記述文を用いる本論文で提案するアプローチだけでなく, 検索項目や検 索条件を詳細に設定する（すなわち，これらの基準で分類された検索辞書を用いる）従来のア プローチにも共通の問題と捉えることができる. 次節では, これらの議論を基に, 手指動作記 述文の正規化の方法と利用について検討する。

\section{5 手指動作記述文の正規化の方法と利用}

2 章で述べたように, 手指動作記述文で用いられる語彙は, 通常の日本語文と比べて制約が 強く，文形式にパターンが存在すると捉えることができる。一般に，このような制限された文 を受理する有限オートマトンは比較的容易に構成できることが知られている．すなわち，正規 文法で手指動作記述文の構文規則を記述できる可能性がある。この文法を構成することは, 検 索記述文と辞書記述文の両方を正規化する言語処理的かつ汎用性のあるアプローチといえる.

一方，(安達 1998) は限られた動作に限定しているが, 人物を背景画像とするパレット上で のマウスの位置とその移動軌跡に基づき, 正規化された手指動作記述文を生成し, 検索記述文 とする検索アプローチを提案している。これは, 前節で議論した視点や曖昧さの問題に対する 1 つの解と考えることができる，すなわち，検索記述文を辞書記述文に近づける正規化の試み の 1 つと捉えることができる．また，(Adachi 1999) は，手指動作記述文が手話表現を生成する 手続き文（プログラム）と捉えた手話アニメーションの生成方法について報告している．これ ら一連の研究では, 手指動作記述文を電子化辞書の情報の中心に据え, 言語と画像の接点とし て, 手話単語の検索と生成を同じ枠組で構成しょうとする提案である. 今後の展開を期待する 試みの 1 つである.

実験では,「両手」を文の特徴付けに寄与しない不要語とみなし，手の形を記述する部分が 「両手」に対して前置される場合と後置される場合の照合洩れを抑止する戦略を採った。一方， 手指動作記述文の正規化, 特に, 単語の配列（文形式）に関して，このキーワード「両手」は 有効利用できる可能性がある。すなわち,「手の形」の手指動作特徵は「両手」の前に置くよう に正規化する方法である。これにより，キーワード照合の際に,「両手」の前部と後部を分けて 
照合すれば，前部は「手の形」に関する類似性であることが明確になり,「手の形」を無視（手 の位置と動きに注目）した検索や「手の形」に注目した検索など，検索手段の幅が広がる可能 性があると考える．本手法では，キーワードに対して重み付けは考慮していない．手指動作特 徵の各パラメータに関連するキーワードに重み付けをし，類似度の計算に反映させる枠組の検 討は, 今後の課題である.

ここで,これまでの議論をまとめると, 本論文で提案した検索方法は, 手話単語の特徵構造 を言語表現に写像した手指動作記述文を用いた検索方法であり，手話単語の検索問題を文献検 索問題と捉えた点に特徵がある.この手指動作記述文は一般の自然言語文に比べて構文的にも 語彙的にも制限のある文集合と捉えることができる。一方，このような制約のある文集合でも， 自然言語表現の持つ特徵である「多義性」や「多様性」に起因する「解釈の曖昧さ」という自 然言語処理全体に共通の問題点を解消する必要がある。この「曖昧さ」を除去するには，手指 動作記述文から得られる情報と得られない情報を区別し，得られる情報でも現在は無視してい る部分（辞書記述文と検索記述文で共通でないキーワードの数やキーワードの持つ意味）を類 似度の計算に組み入れる検討と，与えられた文からは得られない情報（利用者が手話表現を認 知する場合の視点や省略された手指動作特徵など）については，(安達 1998)の手法のように, 言語処理の枠組内ですべて解決するのではなく，言語表現以外の手段により，得られた情報を 基に正規化された言語表現を再構成し，検索記述文とするアプローチなども考慮しながら検討 する必要がある。

このように，本論文で提案した手法を実用レベルの検索精度に高めるには，ここで議論した 手指動作記述文の正規化の問題を解決する必要があるなど, 残された課題は少なくない.また, 検索に失敗した場合の効果的なリカバリー処理についても，今後，検討する必要がある.

\section{6 おわりに}

従来の手話単語の検索方法が，利用者に検索項目や検索条件を詳細に設定させ，検索単語の 候補を絞り込むアプローチを採用していたため, 初心者には適切な設定が困難であり，かつ煩 わしく，その結果として，選択ミスを生じやすく，検索精度を低下させる問題点があった．本論 文では，従来の検索項目や検索条件を設定する代わりに，手指動作記述文を用いた手話単語の 検索方法を提案した. 本手法の特徵は，与えられた入力文に類似している辞書中の手指動作記 述文を検索し, 対応する手話単語の日本語ラベルを提示する点にある.すなわち，手話単語の 検索問題を文献検索問題と捉えたアプローチといえる。両手同形の手話単語を対象に検索実験 を行った結果，本手法の妥当性を示す結果が得られた。また，実験により明らかとなった，手 話表現を日本語文で記述した場合に生じる手指動作記述文の曖昧さに関する問題について検討 を行った. 今後の課題として，入力された手指動作記述文の曖昧さの検出，検索に失敗した場 合のリカバリー処理の検討，および文の正規化による検索精度の向上が挙げられる. 


\section{謝辞}

本研究を進めるにあたり, 有益なご示唆, ご討論を頂いた宇都宮大学鎌田一雄教授, 熊谷毅 助教授に心より感謝する。また，デー夕整理，実験等に協力頂いた研究室の学生諸氏に感謝す る. なお, 本研究の一部は文部省科研費, 厚生省科研費, 実吉奨学会, 電気通信普及財団, 放 送文化基金，トヨ夕自動車，柏森情報科学振興財団，大川情報通信基金の援助によった。

\section{参考文献}

阿部正博, 酒匂裕, 佐川浩彦 (1993). “構文意味解析に基づく手話・文章変換方法.”電子情報通 信学会論文誌, J76-D-II (9), 2023-2030.

安達久博, 吉澤昌三, 藤田均子, 松本崇, 鎌田一雄 (1992). “手話ニュース文の分析と手話変換処 理.” NL91-3, 情処学研報.

安達久博 $(1992 \mathrm{a})$. “手話通訳のためのニュース文の話しコトバへの変換処理.” NLC92-47, 信 学技報.

安達久博 $(1992 b)$. “手話通訳システムの研究動向 — 自然言語処理の立場から.” NLC92-5, 信 学技報.

安達久博, 下山豪彦, 播磨良洋, 松浦威日 (1993). “日本語・手話電子化辞書の構成法について.” NL96-3, 情処学研報.

安達久博 (1998). “手指動作特徵系列を用いた手話単語の類似検索システム.” NL124-11, 情処 学研報.

Adachi, H. (1999). "A Verbal Description-based Approach for Synthesizing and Capturing Sign Animations." In Proceedings of NLPRS'99, pp. 499-502.

安達久博 (2000). “手指動作記述文間の類似性に基づく類似の手指動作特徴を含む手話単語対の 抽出方法.”自然言語処理, 7 (4), 247-259.

Cooper, W. S. (1968). "Expected search length: A single measure of retrieval effectiveness based on the weak ordering action of retrieval systems." American Documentation, 19 (1), 30-41.

鎌田一雄, 藤野淑子, 薄井幸江 (1991). “コンピュータ処理のための手話記述パラメータの基礎 検討.” 聴覚言語障害, 2 (1), 9-15.

鎌田一雄, 松本崇, 山上淳二 (1994a). “日本語・手話変換の基礎検討.” HC93-75, 信学技報.

鎌田一雄, 吉田忠城, 渡辺昌之, 薄井幸江 (1994b). “日本語文・手話単語列変換システムの検討.” AI89-55, 信学技報.

神田和幸, 小田候朗, 本名信行, 加藤三保子 (1984). “日本手話の表記法に関する提案 一 手の形 を中心にして—." S83-88, 日本音響学会音声研究会資料. 
神田和幸, 加藤三保子, 本名信行, 小田候朗 (1985). “日本手話の行動素の表記 一 手の動きを中 心にして—.”S84-102, 日本音響学会音声研究会資料.

加藤雄士, 内藤一郎, 神田和幸 (1993). “手の形態から検索する手話電子辞書の試作.”テクニカ ル・レポート,第 9 回ヒューマン・インタフェース・シンポジウム論文集.

河合秀夫, 田村進一, 岡崎耕三 (1996). “光ディスクによる手話生成システム.”テレビジョン学 会誌, 44 (3), 305-311.

黒川隆夫 (1988). “ヒューマン・インタフェースとしての動作言語.” 計測と制御, 27 (1), 49-55. 丸山浩路編 (1984). イラスト手話辞典. KK ダイナミックセラーズ.

長尾䢐 (1983). 言語工学. 昭晃堂.

長嶋祐二, 神田和幸, 寺内美奈 (1993). “日本手話の階層的形態素解析と電子化辞書のための記 述法.” NLC93-51, 信学技報.

内藤一郎, 安東孝治, 加藤雄士 (1994). “手話学習システムのための電子辞書の検討.” ET93-114, 信学技法.

内藤一郎 加藤雄士 (1996). “効率的な検索方法の確立を目的とした日本手話の形態的特徵の基 礎的検討.”電子情報通信学会論文誌, J79-A (2), 337-345.

中村直人 (1989). “用例検索翻訳支援システム.” 1, 情報処理学会第 38 回全国大会論文集. 大島尚編 (1986). 認知科学. 新曜社.

Reicher, G. M. (1969). "Perceptual recognition as a function of meaningfulness of stimuli material." Journal of Experimental Psychology, 18, 275-280.

佐川浩彦, 酒匂裕, 阿部正博 (1992). “連続手話照合を用いた手話通訳システム.” HI44-12, 情 処学研報.

佐藤理史 (1993)。“用例検索による日英翻訳支援システム CTM2 - 部分列インデックスを用い た最適照合検索 —.”テクニカル・レポート IS-RR-93-61, 北陸先端科学技術大学 情報科 学研究科.

Sato, S. (1992). "CTM: An Example-Based Translation Aid System." In Proceedings of COLING92, Vol. IV, pp. 1259-1263.

Stokoe, W. C., Casterline, D. C., and Croneberg, C. G. (1976). A dictionary of American Sign Language on linguistic principles (new ed.). Linstok Press (originally published in 1965).

隅田英一郎 堤豊 (1991). “翻訳支援のための類似用例の実用的検索法.”電子情報通信学会論文 誌, J74-D-II (10), 1437-1447.

手話研究委員会編 (1986). 改訂版:わたしたちの手話 1. 全日本壟唖連盟.

田中英輝, 熊野正, 浦谷則好, 江原暉将 (1999). “放送ニュース文を対象とした効果的類似用例検 索法.” 自然言語処理, 6 (5), 93-116. 
寺内美奈, 長嶋祐二, 三原浩樹, 長嶋秀世, 大和玄一 (1992). “アニメーションによる日本語手話 表現に関する基礎的検討.” HI41-8, 情処学研報.

寺内睦博 西川誠 (1996). “格表現を伴う日本語文から手話への格構造に基づいた翻訳システム.” 電子情報通信学会論文誌, J79-A (2), 318-328.

Thomas, H. C., Charles, E. L., and Ronald, L. R. (1990). Introduction to Algorithms. MIT Press.

徳田昌晃 奥村学 (1998). “日本語から手話への機械翻訳における手話単語辞書の補完方法につ いて.”情報処理学会論文誌, $39(3), 542-550$.

徳永健伸 (1999). 情報検索と言語処理. 東京大学出版会.

徐軍, 棚橋真, 坂本雄児, 青木由直 (1993). “手話画像知的通信のための手振り記述と単語辞書の

構成法.”電子情報通信学会論文誌, J76-A (9), 1332-1341.

\section{略歴}

安達 久博: 1981 年宇都宮大学工学部情報工学科卒業. 1983 年同大学院工学研 究科修士課程修了. 同年, 東京芝浦電気株式会社 (現. (株) 東芝) 入社. 同 社総合研究所情報システム研究所に所属. この間, (株) 日本電子化辞書研究 所 (EDR)に出向. 1992 年より宇都宮大学工学部助手. 博士 (工学). 現在, 聴覚障害者の情報獲得を支援する手話通訳システムに関する研究に従事. 言 語処理学会, 情報処理学会, 電子情報通信学会, 人工知能学会, 日本認知科 学会, 計量国語学会, 各会員. 